\title{
The Role of Vitamin K Status in Cardiovascular Health: Evidence from Observational and Clinical Studies
}

\author{
A. J. van Ballegooijen ${ }^{1}$. J. W. Beulens ${ }^{2,3}$
}

Published online: 10 July 2017

(C) The Author(s) 2017. This article is an open access publication

\begin{abstract}
Purpose of Review Vitamin $\mathrm{K}$ is a fat-soluble vitamin required for the activation of several vitamin K-dependent proteins to confer functioning. A growing body of evidence supports that vitamin $\mathrm{K}$ has beneficial effects on bone and cardiovascular health. This review summarizes key evidence on vitamin $\mathrm{K}$ status as measured by circulating measures and cardiovascular outcomes.

Recent Findings Overall, observational studies indicate that low vitamin $\mathrm{K}$ status as measured by high dephosphorylated uncarboxylated matrix gla protein concentrations plays a potential role in cardiovascular disease development, particularly in high-risk and chronic kidney disease populations. Very few vitamin $\mathrm{K}$ intervention trials have been conducted with cardiovascular-related outcomes. A couple of intervention trials studied the effect of the combination of vitamin D $+K$ supplementation, which might have synergistic effects compared to vitamin $\mathrm{K}$ supplementation alone.

Summary Assessing vitamin K status in prospective studies and well-designed randomized trials would provide important
\end{abstract}

This article is part of the Topical Collection on Cardiovascular Disease

A. J. van Ballegooijen

hanne.van.ballegooijen@vu.nl

1 Department of Health Sciences, Amsterdam Public Health Research Institute, Vrije Universiteit Amsterdam, De Boelelaan 1085, 1081, HV Amsterdam, the Netherlands

2 Department of Epidemiology and Biostatistics, Amsterdam Public Health Research Institute, VU University Medical Center, Amsterdam, the Netherlands

3 Julius Center for Health Sciences and Primary Care, University Medical Center Utrecht, Utrecht, the Netherlands insight whether vitamin $\mathrm{K}$ is causally related to vascular calcification and cardiovascular disease.

Keywords Vitamin K · Matrix gla protein · Vascular calcification $\cdot$ Cardiovascular disease

\section{Introduction}

Vitamin $\mathrm{K}$ is a fat-soluble vitamin and is mostly known for its function in blood coagulation. Vitamin K was discovered in 1939 by Henrick Dam, who named the molecule vitamin K according to the Danish word for blood clotting koagulation.

Vitamin $\mathrm{K}$ occurs in our diet in two forms: vitamin $\mathrm{K}_{1}$ (phylloquinone) mostly found in green leafy vegetables and vitamin $\mathrm{K}_{2}$ (menaquinones) mainly found in animal foods, fermented dairy such as cheese, and natto (fermented soy beans). Vitamin $\mathrm{K}_{2}$ includes a range of vitamin $\mathrm{K}$ forms and differs from vitamin $K_{1}$ in its side-chain length and degree of saturation. Vitamin $\mathrm{K}_{2}$ is the most biologically active form and has a longer half-life than (days vs. hours) vitamin $\mathrm{K}_{1}$ [1].

Vitamin $\mathrm{K}$ is required as a co-factor in the process of gamma-carboxylation of several vitamin K-dependent proteins turning inactive uncarboxylated proteins into active carboxylated forms to confer functioning. The most well-known vitamin K-dependent proteins are the hepatic coagulation factors prothrombin and factor X. However, other extra-hepatic vitamin K-dependent proteins have been identified as well. Matrix gla protein (MGP) is a small extracellular matrix protein, synthesized in smooth muscle cells, that binds $\mathrm{Ca}^{2+}$ ions in the vascular wall and functions as a potent inhibitor of vascular calcification [2]. Vitamin $\mathrm{K}$ deficiency results in the synthesis of under-carboxylated, biologically inactive gla proteins - a risk factor for vascular calcification and cardiovascular disease (CVD) [3-6]. 
Previous studies mostly relied on dietary intake measures of vitamin $\mathrm{K}$ such as vitamin $\mathrm{K}_{1}$, vitamin $\mathrm{K}_{2}$, and natto intake to study the relationship with chronic diseases and CVD [3, 7, 8]. These studies indicated that a high vitamin $\mathrm{K}$ intake is associated with improved cardiovascular health. However, self-reported dietary intake is imprecise and inherent to limitations to estimate nutrient intakes $[9,10]$. New assay development allows the quantification of various circulating vitamin $\mathrm{K}$ status markers such as plasma vitamin $\mathrm{K}_{1}$ and $\mathrm{K}_{2}$ (menaquinones 4 and 7) and dephosphorylated uncarboxylated MGP (dp-ucMGP) [11]. The purpose of this review is to summarize key evidence on vitamin $\mathrm{K}$ status as measured by circulating measures and cardiovascular-related outcomes in humans. Further, novel insights into the combination of vitamin $\mathrm{D}$ and vitamin $\mathrm{K}$ suggest synergistic effects for cardiovascular health. Vitamin D may preserve vitamin K-dependent protein activity and can thereby contribute to vascular health. Additionally, the interaction with vitamin D is discussed and future research recommendations are given.

\section{Circulating Vitamin K Status Markers}

Circulating nutrient biomarkers are considered more objective measures of nutrient status compared to dietary intake measures and reflect both intake and metabolism. Multiple biomarkers are available to measure vitamin $\mathrm{K}$ status, but none of them is robust enough to be considered "gold standard" [12]. Circulating vitamin $\mathrm{K}_{1}$ concentrations decrease during vita$\min \mathrm{K}_{1}$ depletion and increase with vitamin $\mathrm{K}_{1}$ supplementation [13]. An important limitation of the measurement of plasma vitamin $\mathrm{K}_{1}$ is that it mainly reflects the intake of the previous days due to its relatively short half-life time of $1-3 \mathrm{~h}$ [14].

Menaquinone can be produced by intestinal gut microbiota; however, very little is known about the absorption in the gut and the contribution of the microbiome to vitamin $\mathrm{K}$ status $[1,14]$. Moreover, the vast majority of the gut menaquinone pool is located in bacterial membranes and is probably not available for absorption; however, data is very limited and a better understanding of how and where menaquinone absorption takes place is urgently needed [14].

Circulating menaquinone concentrations have been rarely studied because specific menaquinones are highly dependent on intake of certain foods, which differs per geographical location. For instance, in a normal Western diet, menaquinone-4 is the only vitamin $\mathrm{K}_{2}$ form that is detectable. In a diet without natto intake, menaquinone-7 is often below the limit of detection due to very low concentrations and [11] is only detectable after natto supplementation or menquinone-7 supplementation.

Vitamin $\mathrm{K}$ status can also be estimated by measuring the uncarboxylated fractions of certain vitamin K-dependent proteins such as osteocalcin (a marker of bone formation) or
MGP, which is the most studied vitamin K-dependent protein in the regulation of vascular calcification. MGP is synthesized by smooth muscle cells in the arterial wall, and higher uncarboxylated concentrations of MGP reflect lower vitamin $\mathrm{K}$ status. Since MGP is the main vitamin K status marker of vascular calcification, studies that used osteocalcin concentrations as a marker of vitamin $\mathrm{K}$ status with cardiovascularrelated outcomes have not been taken into account.

Assays that measure total circulating MGP (regardless of its carboxylation status) have been available for some time [4, 5]. Recently, assays that measure different fractions of MGP in circulation have been developed, of which dephosphorylated uncarboxylated MGP (dp-ucMGP) best reflects vitamin K status [6]. It is considered as a functional marker of bioactivity of both vitamin $\mathrm{K}_{1}$ and vitamin $\mathrm{K}_{2}$ over multiple weeks to months [15]. Nowadays, dp-ucMGP is available as a fully automated commercial assay, which makes it a feasible marker as routine laboratory assessment in clinical practice. DpucMGP has been proposed as an extra-hepatic vitamin $\mathrm{K}$ status marker; however, evidence is currently insufficient to support what levels of dp-ucMGP are required for optimal functioning and more research is needed.

Proteins induced by vitamin K absence factor II (PIVKAII) uncarboxylated prothrombin are another functional marker of vitamin K status, also known as des-gamma carboxyprothrombin (DCP). PIVKA-II/DCP is detectable in people with deficiency of vitamin $\mathrm{K}$ (due to poor nutrition or malabsorption) and in those taking warfarin or other medication that inhibits the action of vitamin K. PIVKA-II/DCP has recently been used in general population studies [16, 17]; however, the commercially available assays have low sensitivity for detecting enough variation in PIVK-II concentrations in healthy populations [12]. The exploration of the biochemistry and physiology of vitamin $\mathrm{K}$ biomarkers is ongoing, and relationships with vascular calcification and CVD will be clarified by longitudinal analyses of vitamin $\mathrm{K}$ biomarkers in large population-based studies. Possibly, vitamin K status may be estimated more accurately if multiple biomarkers, or biomarkers in combination with dietary intake, are used.

\section{Cardiovascular-Related Outcomes}

Vascular calcification, regardless of its anatomical site, is a strong risk factor for cardiovascular death [18]. Calcification in the vasculature leads to arterial stiffening, elevated systolic pressure, and increased cardiac workload [19]. There is currently no effective treatment available for vascular calcification, and treatment is targeted to relieve symptoms. Therefore, understanding underlying mechanisms driving these processes is urgently needed to lower the burden of vascular calcification and associated health-care costs. 
A strong body of evidence from experimental animal models indicates that vitamin $\mathrm{K}$ is involved in vascular calcification through carboxylation of MGP [2, 20]. An MGP knock-out model showed extensive calcification in coronary arteries leading to aortic rupture and premature mortality [2]. Further, vitamin $\mathrm{K}$ antagonism due to warfarin antagonizes vitamin K-dependent carboxylation of MGP leading to rapid arterial calcification [21]. In addition, a high vitamin $\mathrm{K}$ diet is able to reverse aortic calcification after warfarin treatment in rats [22].

The relationship between circulating vitamin $\mathrm{K}$ status biomarkers with cardiovascular-related outcomes received growing research interest in the last 5 years. We examined human evidence of circulating vitamin $\mathrm{K}$ status and cardiovascular health, with a particular focus on chronic kidney disease (CKD) patients, a group characterized with a disproportional high risk for vascular calcification and CVD death.

\section{Circulating Vitamin K and CVD-Related Outcomes}

A growing amount of studies assessed the crosssectional relationship between circulating vitamin $\mathrm{K}$ status and CVD-related outcomes [17, 23-29] as depicted in Table 1. In two studies from Norway, univariate correlations were found between higher plasma dp-ucMGP and unfavorable echocardiographic measures; however, multivariable statistical analyses were lacking [28, 29]. The study by Dalmeijer et al. [23] showed that higher plasma dp-ucMGP concentrations indicated a higher trend for a higher coronary artery calcification (CAC) score $\beta 0.091$ (95\% confidence interval, $-0.01,0.19$ ) among post-menopausal women. Liabeuf et al. indicated that higher dp-ucMGP was significantly associated with a higher odds of peripheral arterial calcification score: odds ratio $1.88(1.14,3.11)$ [24]. Higher plasma dpucMGP was consistently associated with higher carotid-femoral pulse wave velocity (cf-PWV) in populations from different countries [25-27]. In the MESA study, no association between circulating DCP and cardiovascular calcification was observed in healthy participants [17].

In a case-control study from the MESA cohort, lower plasma vitamin $\mathrm{K}_{1}$ concentrations were associated with greater coronary artery calcification (CAC) progression in antihypertensive medication users (OR $2.37(1.38,4.09))$, meaning that vitamin $\mathrm{K}$ may mediate vascular calcification among high-risk participants [30••].

Also, longitudinal studies assessed the relationship between circulating vitamin $\mathrm{K}$ status and coronary calcification or incident CVD [16, 31•, 32-35]. Among type 2 diabetes patients, higher dp-ucMGP was associated with incident CVD hazard ratio (HR) 1.21 $(1.06,1.38)[31 \bullet]$. Also, in a general older population, higher plasma dp-ucMGP was associated with a higher risk of incident CVD: HR $2.69(1.09,6.62)$ [34]; however, this could not be confirmed in a cohort of middleage adults: HR $0.94(0.79,1.13)$ [35].

In a cohort of post-menopausal women, higher plasma dp-ucMGP showed a trend for higher coronary calcification risk (RR $1.07(0.99,1.15)$ ), but was borderline significant [32]. On the contrary, in the same cohort, higher plasma vitamin $\mathrm{K}_{1}$ was not associated with a reduced CAC score but was associated with a higher CAC prevalence ratio, $1.36(1.02,1.81)$ [33].

In a multi-ethnic cohort study, higher circulating DCP was associated with a higher risk of ischemic CVD in a population enriched for ankle-brachial pressure $\geq 1.4$ [16]. In a Flemish population study, Mendelian randomization was applied using genetic variation associated with dp-ucMGP concentrations [36]. Dp-ucMGP correlated significantly with rs2098435, rs4236, and rs2430692, major allele carriers having higher dpucMGP concentrations. The instrumental variable analysis did not support a causal association for all-cause and cardiovascular mortality; however, for rs2098435, the HR for coronary events was $0.75(0.59,0.96)$. The authors suggest that the inverse association might be due to inhibition of calcified plaques by active MGP, which is a risk factor in the coronary circulation.

Several prospective studies investigated the relationships between dp-ucMGP concentrations and all-cause mortality among cardiac patients. The studies were performed in Norway and Czech Republic and indicated that higher plasma dp-ucMGP was strongly associated with a higher risk of all-cause mortality [28, 29, 37•]. Further, the study by Mayer et al. indicates that the association is stronger among participants with high Btype natriuretic peptide and dp-ucMGP concentrations for all-cause mortality: HR 2.57 (1.60, 4.10) [26]. This means that high-risk patients may be more prone to the detrimental effects of vitamin $\mathrm{K}$ deficiency. In total, growing evidence points out that a low circulating vitamin $\mathrm{K}$ status as measured by high dp-ucMGP is related to a higher cardiovascular risk; however, this was not consistent in all studies.

So far, vitamin $\mathrm{K}$ intervention trials with hard clinical endpoints are missing. One intervention trial studied the effect of vitamin $\mathrm{K}$ vs. placebo on arterial stiffness in healthy post-menopausal women [38]. After 3 years, the beta stiffness index as a measure of mechanical arterial properties decreased significantly in the menquinone-7 group compared to that of the placebo. More studies are clearly needed to investigate whether vitamin $\mathrm{K}$ supplementation improves cardiovascular health. 
告

实岤

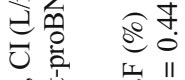

तु่

II กู है

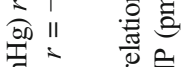

莽?

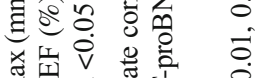

焉零

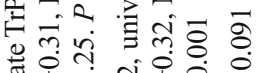

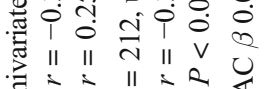

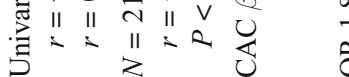

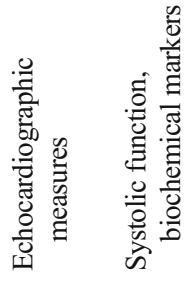

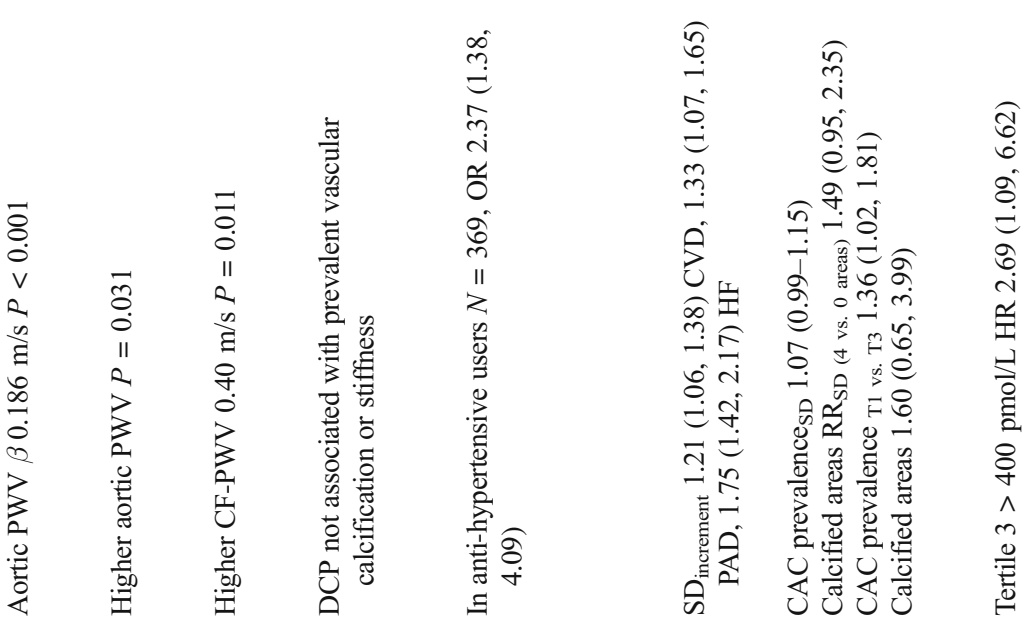

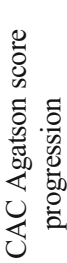

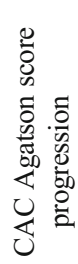

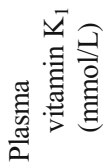

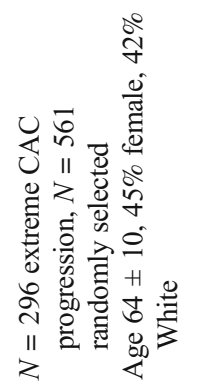

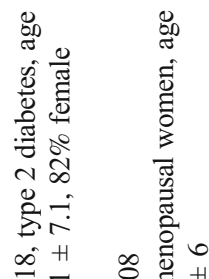

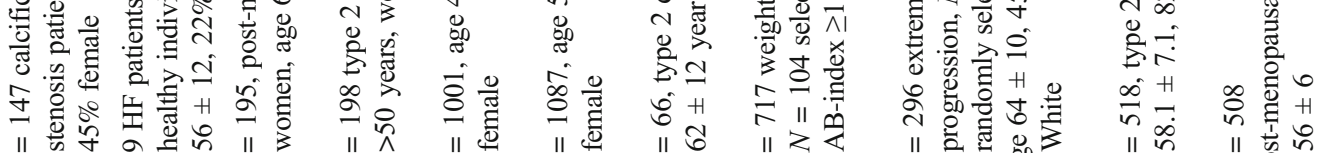

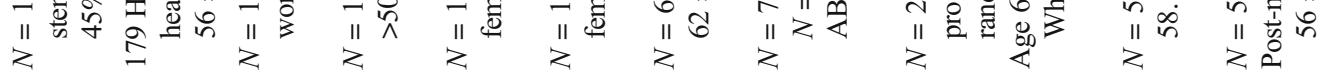

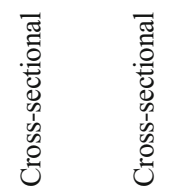

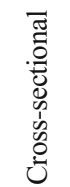

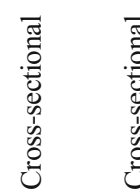

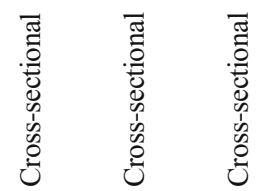

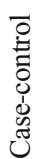

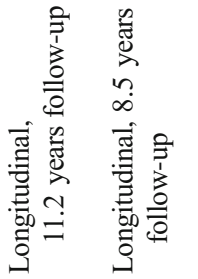

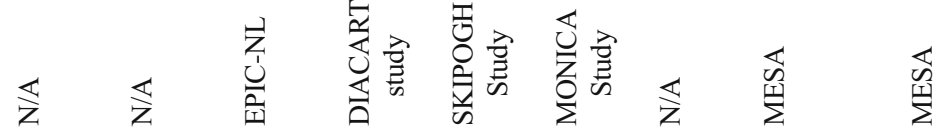

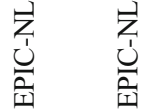

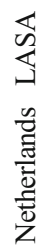

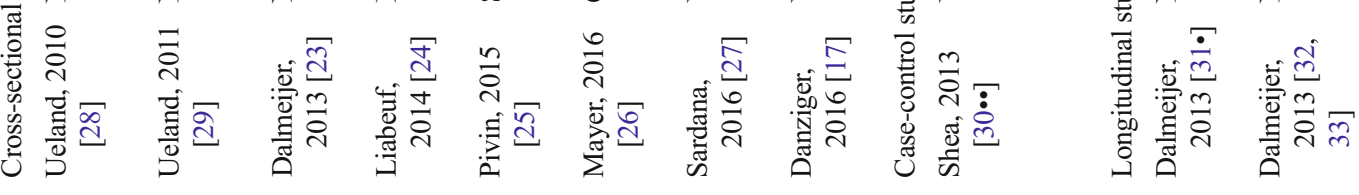

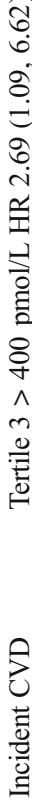




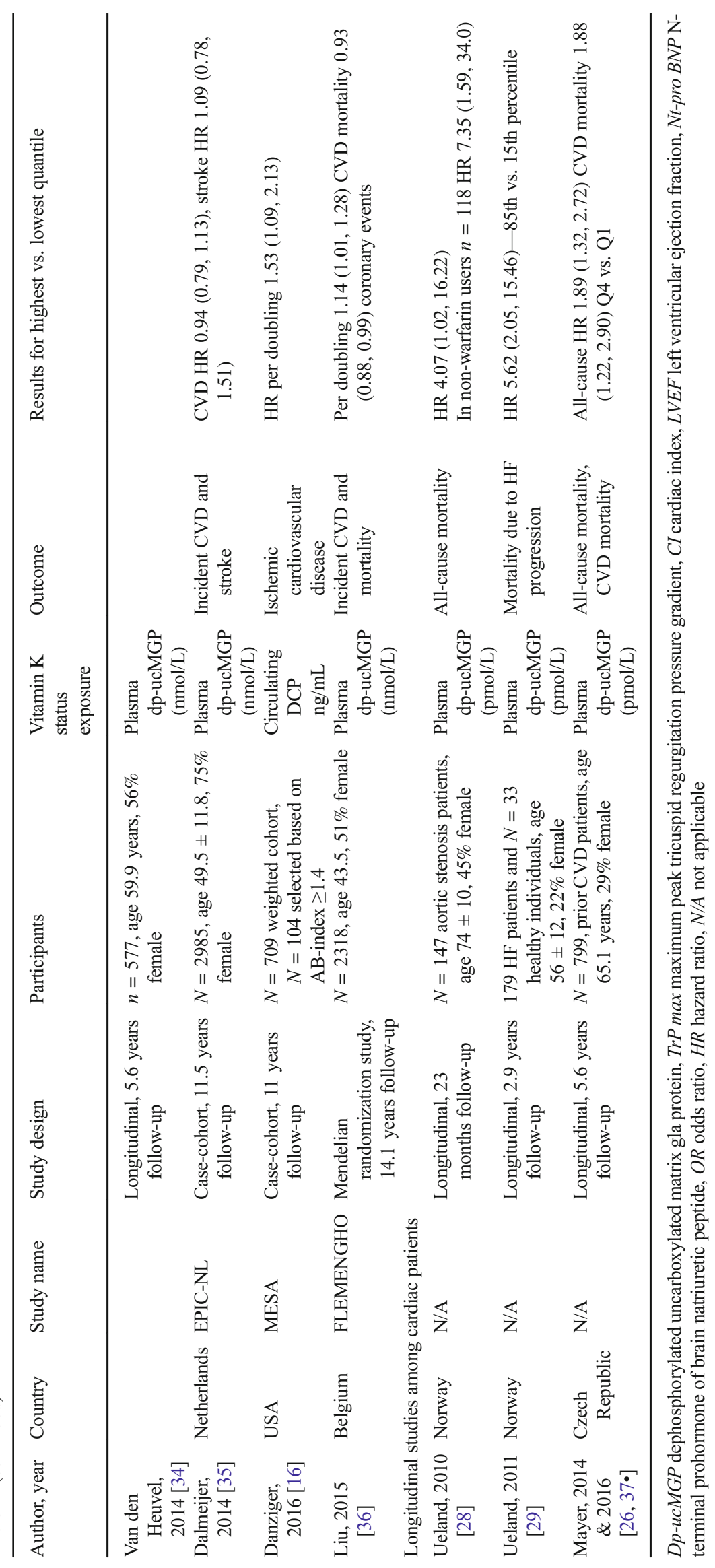


Table 2 Summary of observational studies of circulating vitamin K status and cardiovascular-related outcomes in chronic kidney disease populations

\begin{tabular}{|c|c|c|c|c|c|c|}
\hline Author, year & Country & Study design & Participants & $\begin{array}{l}\text { Vitamin } \mathrm{K} \\
\text { status exposure }\end{array}$ & Outcome & $\begin{array}{l}\text { Results for highest vs. lowest } \\
\text { quantile }\end{array}$ \\
\hline \multicolumn{7}{|c|}{ Cross-sectional CKD studies } \\
\hline $\begin{array}{l}\text { Cranenburg, } 2009 \\
\text { [44] }\end{array}$ & Netherlands & Cross-sectional & $N=40$ hemodialysis patients & $\begin{array}{l}\text { Plasma ucMGP } \\
(\mathrm{pmol} / \mathrm{L})\end{array}$ & CAC scores & $\beta=0.004, P=0.02$ \\
\hline $\begin{array}{l}\text { Delanaye, } 2014 \\
\quad[45]\end{array}$ & Belgium & Cross-sectional & $\begin{array}{l}N=160 \text { hemodialysis } \\
\text { patients, age } 74 \text { years, } 56 \% \\
\text { female }\end{array}$ & $\begin{array}{l}\text { Plasma } \\
\text { dp-ucMGP } \\
\quad(\mathrm{pmol} / \mathrm{L})\end{array}$ & $\begin{array}{l}\text { Calcification } \\
\text { score }\end{array}$ & $\beta=0.19 P=0.021$ \\
\hline $\begin{array}{l}\text { Meuwese, } 2015 \\
\quad[46]\end{array}$ & Sweden & Cross-sectional & $\begin{array}{c}N=97 \text { end-stage renal disease } \\
\text { patients, } 65 \% \text { dialysis, age } \\
45.1 \text { years, } 63 \% \text { female }\end{array}$ & $\begin{array}{c}\text { Dp-ucMGP } \\
\text { (pmol/L), } \\
\text { PIVKA-II } \\
\text { (mAU/ml) }\end{array}$ & $\begin{array}{l}\text { Coronary } \\
\text { calcification } \\
\text { score, arterial } \\
\text { stiffness }\end{array}$ & $\begin{array}{l}\text { Not associated with } \\
\text { calcification, aortic } \\
\text { augmentation pressure } \beta \\
2.2(-1,5.4) \mathrm{NS}\end{array}$ \\
\hline $\begin{array}{l}\text { Thamratnopkoon, } \\
2016 \text { [47] }\end{array}$ & Thailand & Cross-sectional & $\begin{array}{c}N=83 \text { CKD } 3-5 \text { patients, age } \\
64.8 \text { years, } 44 \% \text { female }\end{array}$ & $\begin{array}{l}\text { Plasma } \\
\text { dp-ucMGP } \\
\text { (pmol/L) }\end{array}$ & $\begin{array}{l}\text { Abdominal } \\
\text { aorta } \\
\text { calcification }\end{array}$ & OR $1.002(1.001,1.004)$ \\
\hline \multicolumn{7}{|c|}{ Longitudinal CKD studies } \\
\hline $\begin{array}{l}\text { Schurgers, } 2010 \\
\quad[48]\end{array}$ & France & $\begin{array}{l}\text { Longitudinal } \\
2.2 \text { years } \\
\text { follow-up }\end{array}$ & $\begin{array}{l}N=107 \text { CKD patients stage } \\
2-5, \text { age } 67 \text { years, } 40 \% \\
\text { female }\end{array}$ & $\begin{array}{l}\text { Plasma } \\
\text { dp-ucMGP } \\
\text { (pmol/L) }\end{array}$ & $\begin{array}{l}\text { All-cause } \\
\text { mortality }\end{array}$ & HR $1.57(0.67,3.67)$ \\
\hline $\begin{array}{l}\text { Schlieper, } 2011 \\
\text { [49] }\end{array}$ & Serbia & $\begin{array}{l}\text { Longitudinal } \\
3 \text { years } \\
\text { follow-up }\end{array}$ & $N=188$ hemodialysis patients & $\begin{array}{l}\text { Plasma } \\
\text { dp-ucMGP } \\
\text { (pmol/L) }\end{array}$ & $\begin{array}{l}\text { All-cause } \\
\text { mortality and } \\
\text { CVD } \\
\text { mortality }\end{array}$ & $\begin{array}{l}\text { HR } 2.16(1.1,4.3) \text { all-cause } \\
\text { mortality, } 2.74(1.2,6.2) \\
\text { CVD mortality }\end{array}$ \\
\hline $\begin{array}{l}\text { Keyzer, } 2015 \\
{[50 \bullet \bullet]}\end{array}$ & Netherlands & $\begin{array}{l}\text { Longitudinal, } \\
9.8 \text { years } \\
\text { follow-up }\end{array}$ & $\begin{array}{l}N=518 \text { kidney transplant } \\
\quad \text { recipients }\end{array}$ & $\begin{array}{l}\text { Plasma } \\
\text { dp-ucMGP } \\
\text { (pmol/L) }\end{array}$ & $\begin{array}{l}\text { All-cause } \\
\text { mortality }\end{array}$ & $\begin{array}{l}\text { HR } 2.00(1.20,3.35), \text { Q4 vs. } \\
\quad \text { Q1 }\end{array}$ \\
\hline
\end{tabular}

$D p-u c M G P$ dephosphorylated uncarboxylated matrix gla protein, $C K D$ chronic kidney disease, $N S$ non-significant, $O R$ odds ratio, $H R$ hazard ratio

\section{Chronic Kidney Disease Populations}

Vascular calcification is highly prevalent in CKD patients and is a strong predictor of cardiovascular mortality [39, 40]. Vitamin $\mathrm{K}$ deficiency is also highly prevalent among CKD populations [41, 42]. In experimental CKD models, vitamin $\mathrm{K}$ is key to the susceptibility of vascular calcification [43]. In rats with $\mathrm{CKD}$, the administration of therapeutic doses of vitamin $\mathrm{K}$ antagonists or the use of low vitamin $\mathrm{K}_{1}$ intake markedly increased the degree of vascular calcification. Further, treatment with high doses of vitamin $\mathrm{K}$ increases vitamin $\mathrm{K}$ tissue concentrations, attenuates development of calcification, and restores tissue calcium content comparable to that of nonCKD animals [43].

In observational studies among CKD patients, circulating vitamin $\mathrm{K}$ is related to cardiovascular-related outcomes as depicted in Table 2. It should be noted that most studies are small $(n=40-518)$ and are conducted among patients that are often restricted in potassium-rich foods that are good sources of vitamin K. PIVKA-II is a good marker for vitamin K deficiency in CKD populations, since it is not affected by kidney function; however, studies are very scarce [46].

In cross-sectional studies, higher uncarboxylated MGP [44] and dp-ucMGP [45, 47] were associated with higher calcification scores and prevalent calcification in CKD patients; however, another cross-sectional study could not confirm this
[46]. Longitudinal studies from France, Serbia, and the Netherlands studied relationships between plasma dpucMGP and mortality risk [48, 49, 50••] among different CKD populations. The study by Schurgers et al. did not observe a significant relationship between dp-ucMGP and allcause mortality [48], while the study by Schlieper et al. observed a positive relationship with all-cause mortality: HR $2.16(1.1,4.3)$, which was more pronounced for cardiovascular mortality: HR $2.74(1.2,6.2)$ [49]. Among kidney transplant recipients, Keizer et al. observed a strong association between higher dp-ucMGP concentrations and a higher risk of all-cause mortality over 9.8 years of follow-up [50••]. Taken together, in most CKD populations, higher dpucMGP concentrations are associated with vascular calcification and all-cause mortality, although this was not consistent in all studies. Future studies would benefit from using longterm CVD outcomes in populations with different stages of kidney disease.

\section{Interaction with Vitamin D}

Vitamin D is a fat-soluble vitamin that can be acquired by ingesting foods such as fatty fish, dairy products, and eggs, but is mainly synthesized by the human skin when exposed to sunlight. Vitamin D is metabolized by the kidney for full 
biological activity into its most active form 1,25dihydroxyvitamin $\mathrm{D}$ also known as calcitriol. The role of vitamin $\mathrm{K}$ in cardiovascular health has mainly been studied in isolation; however, new insights suggest a synergistic effect of vitamin $\mathrm{K}$ combined with vitamin D [51-56]. These findings cannot be explained by our current understanding of the biochemical role of vitamin $\mathrm{K}$, but suggest that vitamin D may influence MGP concentrations.

Some animal studies indicate that calcitriol has direct effects on the $\gamma$-carboxylase system by stimulating vitamin Kdependent proteins [51-53], which means that the amount of vitamin $\mathrm{K}$-dependent proteins available for carboxylation is vitamin $\mathrm{D}$ dependent. This may lead to higher circulating levels of under-carboxylated MGP and calcium deposition in the vasculature, which could further increase the risk of vascular calcification and CVD. In vitro studies also support the concept of a synergistic effect of vitamin $\mathrm{K}$ and vitamin $\mathrm{D}$. These studies found that the matrix gla protein gene promoter contains a vitamin D response element, capable of a two- to threefold enhanced matrix gla protein expression after vitamin $\mathrm{D}$ binding [54-56]. The effect of vitamin D combined with vitamin $\mathrm{K}$ on dp-ucMGP is therefore expected to be larger than that of solely vitamin K; however, this should be further explored.

\section{Clinical Trials with Combined Vitamin D and K Supplementation}

So far, two human intervention studies in healthy populations have investigated the combined effect of vitamins $\mathrm{D}$ and $\mathrm{K}$ on vascular function and calcification $[57,58]$. In postmenopausal women after 3 years of supplementation $\left(1000 \mu \mathrm{g} /\right.$ day vitamin $\mathrm{K}_{1}+320 \mathrm{IU}$ vitamin $\left.\mathrm{D}\right)$, the vitamin $\mathrm{D}+\mathrm{K}$ group maintained vessel wall characteristics of the carotid artery, whereas the control group and the vitamin Donly group significantly worsened over 3 years of follow-up [57]. However, vitamin $\mathrm{K}$ status was not measured as a marker of compliance to investigate what occurs following supplementation. Further, in a 3-year, double-blind, randomized controlled trial in older men and women free of clinical CVD, daily supplemental vitamin $\mathrm{K}$ in amounts achievable by high dietary intake of green, leafy vegetables $(500 \mu \mathrm{g} / \mathrm{day})$ combined with $600 \mathrm{mg}$ calcium carbonate and $10 \mu \mathrm{g}$ (400 IU) vitamin $\mathrm{D}$ did not result in lower CAC progression compared to the calcium + vitamin D group. In a subgroup analysis of participants who were $\geq 85 \%$ adherent to supplementation, there was less CAC progression in the vitamin $\mathrm{K}+$ calcium and vitamin $\mathrm{D}$ group than in the calcium and vitamin $\mathrm{D}$ group alone [58]. These data are hypothesis generating, and further studies are warranted to clarify the mechanism.

Two trials studied the effect of vitamin $D$ vs. vitamin $D+K$ in non-dialyzed CKD patients on vascular calcification and cardiovascular risk factors for 9 months [59, 60]. In 42 CKD patients, the increase in common carotid intima-media thickness (CCA-IMT) was significantly lower in the K $(90 \mu \mathrm{g}$ menaquinone-7) $+\mathrm{D}(10 \mu \mathrm{g}$ vitamin $\mathrm{D})$ compared with the D-only group after 9 months [59]. Another small trial $(n=38)$ from the same research group did not show differences between the $\mathrm{D}$ vs. $\mathrm{D}+\mathrm{K}$ group on cardiovascular risk markers [60]. These few studies show some potential for the combined effect of vitamin D + K vs. D alone on cardiovascular-related outcomes. It should be noted that very few clinical studies have been conducted and vitamin $\mathrm{D}$ and $\mathrm{K}$ are combined with different micronutrients making it difficult to solely pinpoint the effect to vitamin $\mathrm{D}+\mathrm{K}$.

\section{Recommendation for Future Research}

- Study the effect of different vitamin $\mathrm{K}$ forms in relation to cardiovascular-related outcomes

- Define the clinical cutoff value for various vitamin K status markers and define vitamin $\mathrm{K}$ deficiency

- Deepen the knowledge on the interaction between vitamins $\mathrm{D}$ and $\mathrm{K}$ and cardiovascular-related outcomes

\section{Conclusions}

Overall, observational studies indicate that vitamin $\mathrm{K}$ has a potential role in cardiovascular health particularly in highrisk and chronic kidney disease populations. Vitamin $\mathrm{K}$ intervention trials with subclinical cardiovascular endpoints are scarce. Most clinical studies investigated the combination of vitamin D + K supplementation, which might have synergistic effects compared to vitamin K supplementation. Vitamin D may preserve vitamin $\mathrm{K}$-dependent protein activity and can thereby contribute to vascular health. Assessing vitamin K status using multiple biomarkers in prospective studies and well-designed randomized trials would provide important insight whether vitamin $\mathrm{K}$ is causally related to vascular calcification and CVD.

\section{Compliance with Ethical Standards}

Conflict of Interest A.J. van Ballegooijen declares that she has no conflict of interest.

J.W. Beulens has received research funding through grants from Unilever R\&D and FrieslandCampina, and compensation for a presentation from the Dairy Council for Northern Ireland, not related to the submitted work.

Human and Animal Rights and Informed Consent This article does not contain any studies with human or animal subjects performed by any of the authors. 
Open Access This article is distributed under the terms of the Creative Commons Attribution 4.0 International License (http:// creativecommons.org/licenses/by/4.0/), which permits unrestricted use, distribution, and reproduction in any medium, provided you give appropriate credit to the original author(s) and the source, provide a link to the Creative Commons license, and indicate if changes were made.

\section{References}

Papers of particular importance that have been published recently are noted as:

- Of importance

•- Of major importance

1. Booth SL, Al Rajabi A. Determinants of vitamin $\mathrm{K}$ status in humans. Vitam Horm. 2008;78:1-22.

2. Luo G, Ducy P, McKee MD, Pinero GJ, Loyer E, Behringer RR, et al. Spontaneous calcification of arteries and cartilage in mice lacking matrix GLA protein. Nature. 1997;386(6620):78-81.

3. Shea MK, Holden RM. Vitamin K status and vascular calcification: evidence from observational and clinical studies. Adv Nutr. 2012;3(2):158-65.

4. Braam LA, Dissel P, Gijsbers BL, Spronk HM, Hamulyak K, Soute BA, et al. Assay for human matrix gla protein in serum: potential applications in the cardiovascular field. Arterioscler Thromb Vasc Biol. 2000;20(5):1257-61.

5. Schurgers LJ, Cranenburg EC, Vermeer C. Matrix Gla-protein: the calcification inhibitor in need of vitamin K. Thromb Haemost. 2008;100(4):593-603.

6. Cranenburg EC, Koos R, Schurgers LJ, Magdeleyns EJ, Schoonbrood TH, Landewe RB, et al. Characterisation and potential diagnostic value of circulating matrix Gla protein (MGP) species. Thromb Haemost. 2010;104(4):811-22.

7. Harshman SG, Shea MK. The role of vitamin $\mathrm{K}$ in chronic aging diseases: inflammation, cardiovascular disease, and osteoarthritis. Curr Nutr Rep. 2016;5(2):90-8.

8. Nagata C, Wada K, Tamura T, Konishi K, Goto Y, Koda S, et al. Dietary soy and natto intake and cardiovascular disease mortality in Japanese adults: the Takayama study. Am J Clin Nutr. 2016;105(2): 426-31.

9. Allen LH. Limitations of current indicators of micronutrient status. Nutr Rev. 2009;67(Suppl 1):S21-3.

10. Westerterp KR, Goris AH. Validity of the assessment of dietary intake: problems of misreporting. Curr Opin Clin Nutr Metab Care. 2002;5(5):489-93.

11. Riphagen IJ, van der Molen JC, van Faassen M, Navis G, de Borst $\mathrm{MH}$, Muskiet FA, et al. Measurement of plasma vitamin K1 (phylloquinone) and $\mathrm{K} 2$ (menaquinones-4 and -7) using HPLCtandem mass spectrometry. Clin Chem Lab Med. 2016;54(7): 1201-10.

12. Shea MK, Booth SL. Concepts and controversies in evaluating vitamin $\mathrm{K}$ status in population-based studies. Nutrients. 2016;8(1):E8.

13. Udall JA. Human sources and absorption of vitamin $\mathrm{K}$ in relation to anticoagulation stability. JAMA. 1965;194(2):127-9.

14. Suttie JW. The importance of menaquinones in human nutrition. Annu Rev Nutr. 1995;15:399-417.

15. Stafford DW. The vitamin K cycle. J Thromb Haemost. 2005;3(8): 1873-8.

16. Danziger J, Young RL, Shea MK, Tracy RP, Ix JH, Jenny NS, et al. Vitamin K-dependent protein activity and incident ischemic cardiovascular disease: the multi-ethnic study of atherosclerosis. Arterioscler Thromb Vasc Biol. 2016;36(5):1037-42.

17. Danziger J, Young RL, Shea KM, Duprez DA, Jacobs DR, Tracy $\mathrm{RP}$, et al. Circulating Des-gamma-carboxy prothrombin is not associated with cardiovascular calcification or stiffness: The Multiethnic Study of Atherosclerosis (MESA). Atherosclerosis. 2016;252:68-74.

18. Kalra SS, Shanahan CM. Vascular calcification and hypertension: cause and effect. Ann Med. 2012;44(Suppl 1):S85-92.

19. Steppan J, Barodka V, Berkowitz DE, Nyhan D. Vascular stiffness and increased pulse pressure in the aging cardiovascular system. Cardiol Res Pract. 2011;2011:263585.

20. Sweatt A, Sane DC, Hutson SM, Wallin R. Matrix Gla protein (MGP) and bone morphogenetic protein-2 in aortic calcified lesions of aging rats. J Thromb Haemost. 2003;1(1):178-85.

21. Price PA, Faus SA, Williamson MK. Warfarin causes rapid calcification of the elastic lamellae in rat arteries and heart valves. Arterioscler Thromb Vasc Biol. 1998;18(9):1400-7.

22. Schurgers LJ, Spronk HM, Soute BA, Schiffers PM, DeMey JG, Vermeer C. Regression of warfarin-induced medial elastocalcinosis by high intake of vitamin K in rats. Blood. 2007;109(7):2823-31.

23. Dalmeijer GW, van der Schouw YT, Vermeer C, Magdeleyns EJ, Schurgers LJ, Beulens JW. Circulating matrix Gla protein is associated with coronary artery calcification and vitamin $\mathrm{K}$ status in healthy women. J Nutr Biochem. 2013;24(4):624-8.

24. Liabeuf S, Bourron O, Vemeer C, Theuwissen E, Magdeleyns E, Aubert CE, et al. Vascular calcification in patients with type 2 diabetes: the involvement of matrix Gla protein. Cardiovasc Diabetol. 2014;13:85.

25. Pivin E, Ponte B, Pruijm M, Ackermann D, Guessous I, Ehret G, et al. Inactive matrix Gla-protein is associated with arterial stiffness in an adult population-based study. Hypertension. 2015;66(1):8592.

26. Mayer O Jr, Seidlerova J, Wohlfahrt P, Filipovsky J, Vanek J, Cifkova R, et al. Desphospho-uncarboxylated matrix Gla protein is associated with increased aortic stiffness in a general population. J Hum Hypertens. 2016;30(7):418-23.

27. Sardana M, Vasim I, Varakantam S, Kewan U, Tariq A, Koppula $\mathrm{MR}$, et al. Inactive matrix Gla-protein and arterial stiffness in type 2 diabetes mellitus. Am J Hypertens. 2017;30(2):196-201.

28. Ueland T, Gullestad L, Dahl CP, Aukrust P, Aakhus S, Solberg OG, et al. Undercarboxylated matrix Gla protein is associated with indices of heart failure and mortality in symptomatic aortic stenosis. $\mathrm{J}$ Intern Med. 2010;268(5):483-92.

29. Ueland T, Dahl CP, Gullestad L, Aakhus S, Broch K, Skardal R, et al. Circulating levels of non-phosphorylated undercarboxylated matrix Gla protein are associated with disease severity in patients with chronic heart failure. Clin Sci (Lond). 2011;121(3):119-27.

30.• Shea MK, Booth SL, Miller ME, Burke GL, Chen H, Cushman M, et al. Association between circulating vitamin K1 and coronary calcium progression in community-dwelling adults: the MultiEthnic Study of Atherosclerosis. Am J Clin Nutr. 2013;98(1): 197-208. This study is a randomized controlled trial, with vitamin $\mathrm{K}$ amounts that are feasible through diet. The study shows that vitamin $\mathrm{D}$ combined with vitamin $\mathrm{K}$ resulted in less progression of CAC in participants adherent to their supplements.

31. Dalmeijer GW, van der Schouw YT, Magdeleyns EJ, Vermeer C, Verschuren WM, Boer JM, et al. Matrix Gla protein species and risk of cardiovascular events in type 2 diabetic patients. Diabetes Care. 2013;36(11):3766-71. This is one of the first studies that estimated associations between circulating vitamin $K$ status and CVD risk, showing that low vitamin $\mathrm{K}$ status is strongly associated with incident CVD.

32. Dalmeijer GW, van der Schouw YT, Magdeleyns EJ, Vermeer C, Elias SG, Velthuis BK, et al. Circulating species of matrix Gla 
protein and the risk of vascular calcification in healthy women. Int $\mathrm{J}$ Cardiol. 2013;168(6):e168-70.

33. Dalmeijer GW, van der Schouw YT, Booth SL, de Jong PA, Beulens JW. Phylloquinone concentrations and the risk of vascular calcification in healthy women. Arterioscler Thromb Vasc Biol. 2014;34(7):1587-90.

34. van den Heuvel EG, van Schoor NM, Lips P, Magdeleyns EJ, Deeg DJ, Vermeer C, et al. Circulating uncarboxylated matrix Gla protein, a marker of vitamin $\mathrm{K}$ status, as a risk factor of cardiovascular disease. Maturitas. 2014;77(2):137-41.

35. Dalmeijer GW, van der Schouw YT, Magdeleyns EJ, Vermeer C, Verschuren WM, Boer JM, et al. Circulating desphosphouncarboxylated matrix gamma-carboxyglutamate protein and the risk of coronary heart disease and stroke. J Thromb Haemost. 2014;12(7):1028-34.

36. Liu YP, Gu YM, Thijs L, Knapen MH, Salvi E, Citterio L, et al. Inactive matrix Gla protein is causally related to adverse health outcomes: a Mendelian randomization study in a Flemish population. Hypertension. 2015;65(2):463-70.

37. Mayer O Jr, Seidlerova J, Bruthans J, Filipovsky J, Timoracka K, Vanek J, et al. Desphospho-uncarboxylated matrix Gla-protein is associated with mortality risk in patients with chronic stable vascular disease. Atherosclerosis. 2014;235(1):162-8. This long-term prospective study among CVD patients indicates that low vitamin $\mathrm{K}$ status is associated with mortality risk.

38. Knapen MH, Braam LA, Drummen NE, Bekers O, Hoeks AP, Vermeer C. Menaquinone-7 supplementation improves arterial stiffness in healthy postmenopausal women. A double-blind randomised clinical trial. Thromb Haemost. 2015;113(5):1135-44.

39. Thompson S, James M, Wiebe N, Hemmelgarn B, Manns B, Klarenbach S, et al. Cause of death in patients with reduced kidney function. J Am Soc Nephrol. 2015;26(10):2504-11.

40. Blacher J, Guerin AP, Pannier B, Marchais SJ, London GM. Arterial calcifications, arterial stiffness, and cardiovascular risk in end-stage renal disease. Hypertension. 2001;38(4):938-42.

41. Holden RM, Morton AR, Garland JS, Pavlov A, Day AG, Booth SL. Vitamins K and D status in stages 3-5 chronic kidney disease. Clin J Am Soc Nephrol. 2010;5(4):590-7.

42. Pilkey RM, Morton AR, Boffa MB, Noordhof C, Day AG, Su Y, et al. Subclinical vitamin K deficiency in hemodialysis patients. Am J Kidney Dis. 2007;49(3):432-9.

43. Schurgers LJ. Vitamin K: key vitamin in controlling vascular calcification in chronic kidney disease. Kidney Int. 2013;83(5):782-4.

44. Cranenburg EC, Brandenburg VM, Vermeer C, Stenger M, Muhlenbruch G, Mahnken AH, et al. Uncarboxylated matrix Gla protein (ucMGP) is associated with coronary artery calcification in haemodialysis patients. Thromb Haemost. 2009;101(2):359-66.

45. Delanaye P, Krzesinski JM, Warling X, Moonen M, Smelten N, Medart L, et al. Dephosphorylated-uncarboxylated matrix Gla protein concentration is predictive of vitamin $\mathrm{K}$ status and is correlated with vascular calcification in a cohort of hemodialysis patients. BMC Nephrol. 2014;15:145.

46. Meuwese CL, Olauson H, Qureshi AR, Ripsweden J, Barany P, Vermeer $\mathrm{C}$, et al. Associations between thyroid hormones, calcification inhibitor levels and vascular calcification in end-stage renal disease. PLoS One. 2015;10(7):e0132353.

47. Thamratnopkoon S, Susantitaphong P, Tumkosit M, Katavetin P, Tiranathanagul K, Praditpornsilpa K, et al. Correlations of plasma desphosphorylated uncarboxylated matrix Gla protein with vascular calcification and vascular stiffness in chronic kidney disease. Nephron. 2016;135(3):167-72.

48. Schurgers LJ, Barreto DV, Barreto FC, Liabeuf S, Renard C, Magdeleyns EJ, et al. The circulating inactive form of matrix gla protein is a surrogate marker for vascular calcification in chronic kidney disease: a preliminary report. Clin J Am Soc Nephrol. 2010;5(4):568-75.

49. Schlieper G, Westenfeld R, Kruger T, Cranenburg EC, Magdeleyns EJ, Brandenburg VM, et al. Circulating nonphosphorylated carboxylated matrix gla protein predicts survival in ESRD. J Am Soc Nephrol. 2011;22(2):387-95.

50.• Keyzer CA, Vermeer C, Joosten MM, Knapen MH, Drummen NE, Navis G, et al. Vitamin K status and mortality after kidney transplantation: a cohort study. Am J Kidney Dis. 2015;65(3):474-83.

This longitudinal study with long-term follow-up provides evidence that vitamin $\mathrm{K}$ status is associated with a strong risk of mortality after kidney transplantation.

51. Fu X, Wang XD, Mernitz H, Wallin R, Shea MK, Booth SL. 9-Cis retinoic acid reduces 1alpha,25-dihydroxycholecalciferol-induced renal calcification by altering vitamin K-dependent gamma-carboxylation of matrix gamma-carboxyglutamic acid protein in A/J male mice. J Nutr. 2008;138(12):2337-41.

52. Arbour NC, Darwish HM, DeLuca HF. Transcriptional control of the osteocalcin gene by 1,25-dihydroxyvitamin D-2 and its 24epimer in rat osteosarcoma cells. Biochim Biophys Acta. 1995;1263(2):147-53.

53. Seyama Y, Horiuch M, Hayashi M, Kanke Y. Effect of vitamin K2 on experimental calcinosis induced by vitamin D2 in rat soft tissue. Int J Vitam Nutr Res. 1996;66(1):36-8.

54. Breen EC, van Wijnen AJ, Lian JB, Stein GS, Stein JL. In vivo occupancy of the vitamin $\mathrm{D}$ responsive element in the osteocalcin gene supports vitamin D-dependent transcriptional upregulation in intact cells. Proc Natl Acad Sci U S A. 1994;91(26):12902-6.

55. Fraser JD, Price PA. Induction of matrix Gla protein synthesis during prolonged 1,25-dihydroxyvitamin D3 treatment of osteosarcoma cells. Calcif Tissue Int. 1990;46(4):270-9.

56. Miyake N, Hoshi K, Sano Y, Kikuchi K, Tadano K, Koshihara Y. 1, 25-Dihydroxyvitamin D3 promotes vitamin K2 metabolism in human osteoblasts. Osteoporos Int. 2001;12(8):680-7.

57. Braam LA, Hoeks AP, Brouns F, Hamulyak K, Gerichhausen MJ, Vermeer C. Beneficial effects of vitamins D and $\mathrm{K}$ on the elastic properties of the vessel wall in postmenopausal women: a follow-up study. Thromb Haemost. 2004;91(2):373-80.

58. Shea MK, O'Donnell CJ, Hoffmann U, Dallal GE, Dawson-Hughes B, Ordovas JM, et al. Vitamin K supplementation and progression of coronary artery calcium in older men and women. Am J Clin Nutr. 2009;89(6):1799-807.

59. Kurnatowska I, Grzelak P, Masajtis-Zagajewska A, Kaczmarska M, Stefanczyk L, Vermeer C, et al. Effect of vitamin K2 on progression of atherosclerosis and vascular calcification in nondialyzed patients with chronic kidney disease stages 3-5. Pol Arch Med Wewn. 2015;125(9):631-40.

60. Kurnatowska I, Grzelak P, Masajtis-Zagajewska A, Kaczmarska M, Stefanczyk L, Vermeer C, et al. Plasma desphospho-uncarboxylated matrix Gla protein as a marker of kidney damage and cardiovascular risk in advanced stage of chronic kidney disease. Kidney Blood Press Res. 2016;41(3):231-9. 